\title{
MOTIVATION AND JOB PERFORMANCE OF UNIVERSITY WORKERS: A CASE STUDY OF PLATEAU STATE UNIVERSITY BOKKOS
}

\author{
Hajaratu Deme Bott, Kaneng Tina Asaju \\ Department of Sociology, Faculty of Social Sciences,Plateau State University, Bokkos-Nigeria \\ E-mail address: nkasiobisilasoguzor@yahoo.com
}

Keywords: Motivation; man; employee; performance

\begin{abstract}
In the field of management, performance and motivation are closely related and familiar terms.However, many managers either do not fully understand or appreciate the intricacies of the theories and practice of motivation.This paper establishes the role of motivation in organizational job performance, it also suggests ways of maintaining and sustaining workers motivation.It establishes that there is a strong relationship between motivation and job performance. The paper looks at the Sociological perspective of organizational job motivation under: Man as an employee, theories of motivation and the role of motivation on performance.Secondary sources of data were mainly used in gathering the information for this paper.
\end{abstract}

\section{INTRODUCTION}

A positive correlation tends to exist between job performance and motivation in the field of management. However management do not seem to fully understand the intricacies of the theories and practice of motivation.

Some questions intrigue the mind concerning motivation. Do managers fully understand the people they work with in order to understand their needs and motivate them? What is the relationship between motivation and job performance? Is motivation a once for all affairs? How do we maintain and sustain employee's motivated spirit? Once motivated will employees remain continually motivated?

\section{THE NATURE OF MAN AS AN EMPLOYEE}

Man is a social being who desires to associate with others in order to achieve some of his goals that he might not otherwise be able to achieve alone, perhaps because of physical, biological and mental limitations. An employee has a number of aspirations and goals which he/she wants to achieve through membership of an organisation. The organ in question will be able to assist him or her to achieve desired personal goals. The hope and believe that the personal goals and aspiration can be achieved are major motivating factors for an individual's membership of an organization.

Of all the preconditions for effective management of an organization, the most vital is the human resource. The success of any organization is predicate upon the human beings that make up that organization (Akerele, 1992). This is primarily because human beings take decisions, provide the knowledge, energy and cooperation through which organizational objectives are achieved. Other resources have to be coordinated and managed by people for the achievement of organizational objectives. Each individual at work has his or her set of values drives, perception, fears, goals, experiences that inform his/her behaviour at work place. Human labour as a special resource, requiring special attention was for long acknowledged by karl max and federick Engels. Man would pursue social conditions, which will liberate, rather than frustrate or deform his personality development 
Man as a distinctive productive force among other productive forces makes its management problematic. He reacts in complex ways to decision, social relationships and situation. In most cases, these reaction are unpredictable. Thus despite advanced studies in behavioural sciences, the psychology and sociology of motivation remains a complex area of study (Onoge, 1992).

\section{OVER VIEW OF THEORIES OF MOTIVATION}

One of the explanations given for differences in performances between individuals or group apart from innate abilities, and skills is the issue of motivation. At any time people vary in their ability and willingness to direct energies towards the attainment of organisations objectives. The conceptand theories of motivation are concerned with the "whys" of human behaviour. That is why people behave the way they do? Motivation is an internal psychological process which is not directly observable, but which accounts for most human behaviour. It is the inner state that energies, activates, moves, impels, directs and channels behaviour towards a goal or goals. Motivation is action pack.

The term motivation and behaviour are closely related, in that most human behaviours occur as a result of motivation. Motivation can be viewed in terms of needs, drive goal. A need is an indication of deficiency in something. This deficiency creates tension in the individual who by exhibiting some behavioural tendencies to overcome the deficiency. Human needs may be innate or acquired. Innate needs are not conditioned by experience. Whereas acquired needs vary greatly from individual to individual, and from group to group. Needs are primarily and culturally determined, but may also be acquired from parents and friends.

Abraham Maslow was one of the first behavioural scientists to study human needs. $\mathrm{He}$ classified needs into a hierarchical order. According to him, individuals are motivated to engage in behaviours that fulfil their needs. Once a particular need is satisfied it ceases to be a motivating factor. The satisfaction of such a need gives rise to the emergence of a higher-order need. In practice, a particular need does not have to be satisfied hundred percent before switching to the next need. The degree to which a particular need is satisfied before attention changes to the next hierarchy will vary from individual to individual.

When needs are not satisfied, the individual exhibits a number of behavioural patterns which are themselves defensive in nature, such as:

Withdraw: Here the individual avoids situation by leaving the scene.

Aggression: Here the individual directs attacks on the source.

Displacement: Here the individual transfers aggression to innocent persons, for examples, his wifelhusband.

Compensation: Here the individual tries to make up for deficiencies, by exhibiting "strange" behaviour for example, a lady getting so involved with children after being jilted.

Rationalization: The individualpresents a reason for the behaviour that is false. Here, he could attribute his poor performance to bad state of machine or hatred for boss.

Herzberg (1968). Provided another model of motivational field (the factor theory of motivation) Herzberg and his associates in their study interviewed a number of accountants and engineers to find out from them when they felt bad (that is, dissatisfied). They complained about pay, company policy, supervision, work conditions andinterpersonal relations. Herzberg called them contextual or environmental conditions, which he labelled dissatisfied.

When they felt good (the satisfiers), they were recognized, had a strong sense of achievement, the work itself was interesting, the feeling of responsibility and advancement was present. 
Herzberg concluded that the presence of contextual factors do not create satisfaction, rather it prevents dissatisfaction-hence labelled 'hygiene factor'. According to Herzberg the satisfiers are motivating factors whereas, the dissatisfiers are not. However, studies by different discipline over the years have shown that Herzberg's two-factor theory has less practical value in developing economies where majority of people still battle with the basic needs (food, shelter and clothing) for survival.

This view was shared by Agbato (1990) page 57 when he said:

.....one our part in Nigeria: in discussing motivation we should not ignore an important factor...... that is our society, our environment. In Nigeria for example and in plateau state university in particular an average worker will not be motivated in the first place by money..... That is, what is there for me? That a Nigeria worker will only be prepared to do his level best if he is sure of adequate compensation, which is more money before other "luxuries".

According to Agbato environment and the circumstances of a people have significant effects in terms of value when discussing employee motivation.

Victor vroom and his associates in their expectancy theory of motivation believed that whether an individual will work hard or not depends on the individuals expectation, that is, what he expects to get from working hard. Expectancy refers to a person's judgement of the likelihood that a specific outcome will follow from a specific course of action. Expectancy is a subjective probability estimate which may vary highly realistic to totally unrealistic. The higher the value placed on a particular outcome (e.g. promotion) the more motivated an individual will become. The individual will tend to work harder in order to earn the promotion.

\section{ROLE OF MOTIVATION ON PERFORMANCE}

Vroom (1964) has asserted "given some values of ability greater than zero, level of performance is constantly increasing function of amount of motivation. That is to say that the more motivated the worker to perform effectively, the more effective is his performance."

Brich (1945) conducted an experiment to show the disruption effects of high levels various lengths of food deprivation. The solution of each of the problems requires the animal to use materials provided (e.g string, rope, or stick ) to obtain food. Brich found the intermediate length of food deprivation, which we can assume to represent the intermediate level of motivation to get food, to be the most conducive to problem solving efficiency. Relatively short and relatively long periods of food deprivation resulted in less efficient behaviour. This experiment demonstrates the different bases for the ineffective performance of animals under condition of very low and very .high motivation.

The nature of the relationship between the amount of motivation and level of performance may vary somewhat with the task being handled. Most investigators have suggested that the inverted U- function must closely approximates the actual state of affairs. According to McClelland (1951) - - - - as a motive increases in intensity it first leads to an increase in the efficiency of instrumental activity and then to a decrease. Too little motivation leads to sluggishness and inertia and too much leads to disruption and defense against anxiety.

The question which we may want to ask is, why should performance decrease with increase in motivation? The answer to this question may be more than one, but one type of motivation all the time may produce negative results. For example, the federal government rewarding system ( motivation ) with respect to the Nigeria national term has proved the theory right.

\section{RECOMMENDATIONS}

The following factors encourages motivation in an organization.

Rule compliance or conformity to system norms. Those in position of authority should show the way by complying with existing rules and regulations of the organization. Adherence to impartial rules. 
Enough benefits for being members of the organization. Such benefits attract people into the organization and equally hold them back.

Rewards for specific contribution. Award night to honour individuals who have made specific contribution.

Interesting jobs that will make an individual dishonour an offer that is financially more rewarding. Creating conditions in which individuals internalized the values of the organization. There is no significant shift between the goal of the organization.

Social satisfaction derived from primary_group relationship: one of the things people miss most when they have to withdraw from organization is the sharing of experiences with like-minded colleagues, the belonging to a group with which they become identified.

Recognizing employees' needs and promptly responding to them.

Making employees feel they are important in the scheme of things.

\section{CONCLUSION}

We have tried to look at the role of motivation in relation to job performance. Studies have shown some positive relationship between motivation and employee job performance and satisfaction.

We have also tried to show that low motivation has the same negative effect on performances as much as high motivation. Appropriate dosage of motivation is required for good job performance.

Motivation should not be a once and for all affairs, rather there must be reinforcing elements to keep it sustained.

The socio-environmental peculiarities of workers play significant role in determining what motivates them and what does not.

\section{References}

[1] Agbato O.J.(1990). The Nature of Management: A text for Professional(Revised ed) abiola Bookshop press Ltd. Ikeja.

[2] Akerele, A. (1992)."The impact of culture of human resources management " Journal of personnel management. vol.5 No. 2 PP7-13

[3] Herzberg, F. (1968)" one more time. How do you motivates employees?' Harvard Business Review: January-February pp. 56-62

[4] Hicks, G. H. and Gullet,R.C.(1976). The management organisations. McGraw-Hill, Inc New York.

[5] Ocholi, S. A. (1994). "Human resources requirements: A motivation approach" A paper presented in a workshop for bank work held at lomay international hotel, Jos.

[6] Onoge, E.O. (1992). "'The positive use of ouota system in the management of human resources. Journal of personnel management. Vol. 5. No. 2 pp 15-20

[7] Vroom, v. (1964). Work and motivation. Penguim books. 